\title{
EDUCATIONAL APPLICATION OF HYPERMEDIA
}

\section{Marek RYBAKOWSKI}

\section{EDUKACYJNE ZASTOSOWANIA HIPERMEDIÓW}

\author{
(WALAT, W. Edukacyjne zastosowania hipermediów. Rzeszów : Wydawnictwo Uniwersytetu \\ Rzeszowskiego, 2007. 320 s. ISBN 978-83-7338-329-6.)
}

Książka autorstwa Wojciecha Walata pod tytułem "Edukacyjne zastosowania hipermediów", dotyczy niezwykle ważnej oraz aktualnej problematyki i swoją treścią wypełnia lukę wydawniczą określoną $w$ jej tytule. Zdecydowanie wzbogaca także metodologię przygotowywania i optymalizacji hipermedialnych programów dydaktycznych oraz otwiera nową perspektywę badawczą w obszarze projektowania dydaktycznego.

Jak pisze jej autor: „Hipermedialne programy dydaktyczne uznawane za nowoczesne opracowania dydaktyczne w swojej istocie budowane są $\mathrm{W}$ zgodzie z ustalonymi już kilkadziesiąt lat temu zasadami programowania dydaktycznego, jednak $\mathrm{w}$ formie całkowicie odmiennej

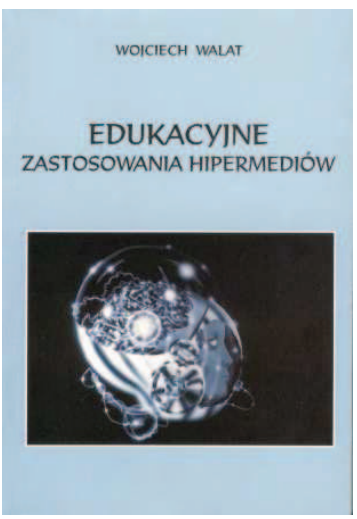
dotychczasowych tekstów programowanych. Ich przygotowanie w oparciu o najnowocześniejsze rozwiązania $\mathrm{z}$ zakresu technologii informacyjnych pozwala budować porcje informacji jako multimedialne komunikaty, różne $\mathrm{w}$ zależności od charakteru i celu przekazu. Z kolei zastosowanie hipertekstu pozwala łączyć ze sobą poszczególne moduły (większe lub mniejsze) bloki programu tak, że w sposób niezauważalny dla ucznia wyznaczana jest jego indywidualna droga uczenia się". Autor przedstawia $\mathrm{W}$ sposób jasny i otwarty dla czytelnika nowe możliwości pewnej algorytmizacji procesu dydaktycznego. Nie ma tu mowy o dehumanizacji i automatyzacji systemu dydaktycznego przez zastąpienie nauczyciela maszyną czy programem, ale o usprawnieniu tych jego aspektów, w których potrzebna jest taka forma, która odpowiada aktualnym sposobom uczenia się „naturalnego" w środowisku ucznia.

Pierwsza część książki dotyczy określenia przydatności klasycznych już dziś metod programowania dydaktycznego w projektowaniu hipermedialnych programów dydaktycznych.

Część druga pozwala czytelnikowi na zapoznanie się szczegółowo $\mathrm{z}$ procedurą projektowania hipermedialnych programów dydaktycznych, poczynając od określenia celu poprzez analizę dydaktyczną, charakterystykę właściwości ucznia - przyszłego użytkownika programu, sformułowanie wiązki celów operacyjnych, wybór strategii nauczania, opracowanie materiałów dydaktycznych (czyli właściwego programu), aż po przygotowanie narzędzi umożliwiających przeprowadzanie kontroli bieżącej i końcowej (sumującej) osiągnięć uczniów.

Część trzecia, to kompletna metodologia badań HPD. Przedstawiona metodologia badań szczegółowych programów dydaktycznych została oparta o zebranie opinii przyszłych jego użytkowników: nauczycieli i uczniów. Uważny czytelnik może nauczyć się, w oparciu o prowadzone badania własne autora książki, jakimi metodami, technikami i narzędziami można określać sprawność potencjalną HPD w funkcji efektywności kształcenia, a także, jak optymalizować hipermedialne programy dydaktyczne. Jako główne metody weryfikacji HPD autor zaproponował: sondaż diagnostyczny, matematyczną analizę treści, obserwację i wywiad oraz eksperyment dydaktyczny. Podane metody pozwalają wskazać braki i konieczne zmiany, jakie należy zastosować w przygotowanym wcześniej programie.

Prowadzone przez W. Walata badania ujawniają, które $\mathrm{z}$ wyróżnionych czynników decydują o powodzeniu zastosowania HPD w procesach dydaktycznych: inny niż zwykle sposób prowadzenia zajęć, możliwość indywidualizowania tempa i treści uczenia się, możliwość korzystania $\mathrm{z}$ dodatkowych źródeł informacji (teksty uzupełniające, rozszerzające, strony internetowe, symulacje), zapewnienie pełnego sprzężenia zwrotnego, samokontrola i samoocena efektów pracy, możliwość swobodnej pracy nieograniczonej sztywnymi 
ramami tradycyjnej lekcji, przemienność form pracy: indywidualnej i grupowej.

Praktyka szkolna oraz podejmowane w różnych aspektach badania nad wykorzystaniem multimediów i hipertekstu w edukacji pozwalają wyprowadzić twierdzenie, że HPD ani nie wyprą tradycyjnych opracowań dydaktycznych, ani nie zdominują procesu dydaktycznego. Należy zgodzić się z autorem książki, że: „W zależności od celów - rodzaju treści kształcenia - zadań dydaktycznych stają się w wielu przypadkach niezbędnym środkiem umożliwiającym ich osiąganie. Ożywiają to, co dotychczas było „zamknięte" w słowach zapisanych w klasycznych podręcznikach szkolnych. Sprawiają, że komunikowanie się nauczyciela z uczniem i ucznia z nauczycielem odbywa się w atrakcyjny sposób, sprawiają, że uczeń nabywa kompetencji takich jak sprawne porozumiewanie się, praca $\mathrm{w}$ zespole, nauka z wykorzystaniem technologii informacyjnych".

Przedstawiona przez autora książki problematyka związana $\mathrm{z}$ projektowaniem i weryfikacją hipermedialnych programów dydaktycznych jest bardzo aktualna. Jako przedmiot badań pedagogicznych, moim zdaniem, potraktowana została komplementarnie, systemowo i zarazem kompletnie. Podjęty przez W. Walata wysiłek badawczy identyfikuje trzy kierunki projektowania i optymalizacji HPD: uzasadnienie konieczności stosowania technologii informacyjnych $\mathrm{w}$ procesach dydaktycznych z punktu widzenia kompetencji informacyjnych (alfabetyzacji informacyjnej uczniów), przygotowanie procedury projektowania opracowań dydaktycznych z wykorzystaniem nowoczesnych technologii pozyskiwania, przetwarzania, przechowywania i przesyłania informacji oraz określenie metod weryfikacji tego rodzaju opracowań.

Poddana mojej recenzji książka, to monografia, która znalazła moje przychylne przyjęcie. Prezentowane treści to dobre kompendium wiedzy dla tych wszystkich, którym bliska jest problematyka stosowania technologii informacyjnych $w$ procesach dydaktycznych.

Prezentowana i oceniana publikacja adresowana jest, moim zdaniem, do nauczycieli, zwłaszcza nauczycieli projektujących i przygotowujących samodzielnie opracowania dydaktyczne $\mathrm{z}$ wykorzystaniem nowoczesnych środków multimedialnych. Może okazać się także przydatna studentom przygotowującym się do pracy nauczycielskiej a także nauczycielom akademickim. Jest publikacją cenną, potrzebną i w istotny sposób uzupełniającą wiedzę na temat określony jej tytułem oraz w relacjach zachodzących pomiędzy poszczególnymi jej częściami. Wydana książka z całą pewnością jest ważną i przydatną pozycją polskiej literatury naukowej.
Marek Rybakowski, dr inż.,
Uniwersytet Zielonogórski, PL
Instytut Edukacji Techniczno-Informatycznej, e-mail: M.Rybakowski@eti.uz.zgora.pl 